\title{
Identification of Candidate Microsatellite Markers Associated with Agronomic Traits in Rice (Oryza sativa L.)
}

\author{
M. Z. Mattar' ${ }^{1}$ Kh. F.M. Salem ${ }^{2 *}$ and A. B. El- Abd ${ }^{3}$ \\ ${ }^{1}$ Botany Department, Faculty of Science, Menoufia University, \\ ${ }^{2}$ Plant Biotechnology Department, Genetic Engineering and \\ Biotechnology Research Institute (GEBRI), Sadat City University, \\ Sadat City and ${ }^{3}$ Rice Research Department, Filed Crops Research \\ Institute, Agriculture Research Center (ARC), Giza. Egypt.
}

\begin{abstract}
A DIVERSE collection of Egyptian and exotic rice genotypes, were evaluated for agronomic traits. Subsequently in order to assess the allele diversity of quantitative trait loci (QTLs) attributed to agronomic traits. The genotypes were characterized using a set of 23 microsatellite markers. In total, 24 significant marker-trait associations QTLs were identified; 2 for heading date, 10 for plant height, 2 for panicle length, 4 for number of panicles per plant, 1 for number of filled grains per panicle, 1 for 1000-grain weight and 4 for grain yield per plant. More of these QTLs were located on chromosomes 2 and 7. Association analysis of SSR markers showed 4 markers RM6, RM118, RM151 and RM307 had significant association with most of agronomic traits. Detection of QTLs for agronomic traits at different chromosomes indicated that these characters are controlled by multiple loci. Higher $\mathrm{R}^{2}$ values were obtained for most traits and ranged from $-0.366^{*}$ to $0.695^{* *}$ for grain yield per plant and plant height, respectively. Genetic analysis identified the best rice microsatellite markers attributed to agronomic traits and they can be informative for improvement of agronomic traits through marker-assisted selection. Breeders can use this information to design crosses that assemble new potentially durable combinations of genes/QTLs to improve rice genotypes.
\end{abstract}

Keywords: Agronomic traits, Allele size, Marker-trait associations, Microsatellite, Oryza sativa, QTLs, Rice

Rice (Oryza sativa L.) is the second most important staple food crop for more than half of world's population (Delseny et al., 2001 and Feng et al., 2013). Grain yield is one of the most important and complex traits in cereal crops that does not evolve independently but shows correlations with other yield components traits. Thus, breeders have to consider correlated traits in breeding

salemcairo@yahoo.com $^{*}$ Author for correspondence E-mail: 
programs. Grain yield and its related traits are quantitatively inherited and controlled by many genes with small effects subject to environmental effects (Inostroza et al., 2009 and Shi et al., 2009). Genetic improvement of yield remains a major breeding objective to meet the ever increasing demand for food. In rice, grain weight is one of the three main yield components, the other two being number of panicles per unit area and number of grains per panicle (Fan et al., 2009). Hence, estimation of the positions and effects of quantitative trait loci $(Q T L s)$ for agronomic traits related to yield is vitally important for marker-assisted selection for yield improvement (Li et al., 2011). QTLs related to yield have been identified through classical linkage mapping approaches (Moncada et al., 2001, Jiang et al., 2004, and Suh et al., 2005). With a few exceptions, most of these QTLs have not been successfully validated or consistently used in crop improvement (Bernardo, 2008).

Classical approaches are too simplistic to effectively model most of the genetic variation for complex traits, because they are unable to reflect the genetic realities of these traits (Cooper et al., 2005 and Holland, 2007). In rice markerassisted selection (MAS) is a promising technique to enhance traits with economic and agricultural value (Yamamoto et al., 2009). DNA markers for genes/QTLs determined agronomic traits allow breeders to precisely select plans with beneficial traits in breeding programs. Marker-assisted selection (MAS) enhanced the cropping potential of an elite cultivar by enabling the development of versions of the cultivar with diverse heading dates. Four QTLs for heading date $H d 6, H d 1$, $H d 4$, and Hd5 were introgressed (Takcuchi et al., 2006). Association mapping, has been practiced a number of plant species (Agramma et al., 2007; Mazzucato et al., 2008, Zhu et al., 2008 and Xu et al., 2014). Association mapping has the potential of simultaneous discovery of gene lock responsible for multiple traits with no need to develop permanent segregating populations.

As association mapping exploits the historical recombination events that have occurred during establishment of the sample population, higher mapping resolution could be obtained than that possible in small bi-parental experimental crosses (Flint-Garcia et al., 2005). This strategy has an attractive advantage in the ability to detect the comparative effects of multiple alleles at each genetic locus that exists in crop germplasm. Association mapping is a powerful tool for identifying quantitative trait loci $(Q T L)$, because it takes advantage of accumulated historic recombination events in natural populations. Therefore, it should be promising for identifying causative polymorphisms of complex traits (Stich et al., 2008). In particular, this approach is superior when genotypes are selected from breeding populations or collections (Thornsberry et al., 2001 and Kraakman et al., 2004).

However, association mapping is complicated by population structure in most germplasm sets (Flint-Garcia et al., 2003). Blast resistance gene pi21 was found to be linked with gene(s) associated with inferior eating quality (Fukuoka et al., 2009). Zhang et al. (2005) successfully conducted whole-genome

Egypt. J. Bot., 56, No. 1 (2016) 
association analysis between microsatellite markers and multiple agronomic traits using discriminant analysis (DA) in 218 inbred lines of rice. Iwata et al. (2007) associated RFLP markers with the width and length of milled rice grains in a set of 332 rice germplasm using Bayesian method. SSR markers and their allele diversity are useful to effectively distinguish rice genotypes. This approach is now being used to differentiate rice germplasm with different sources of mineral elemental contents and phenotypic traits (Zeng et al., 2009). Also, this approach used to differentiate rice germplasm for grain weight $G W 2$ (Dixit et al., 2013), through the use of microsatellite markers. QTLs mapping of many important agronomic traits, a major goal in plant breeding, requires informative markers in an intra-specific context. The objectives of this study were to i) detect chromosomes that control agronomic traits, ii) determine candidate rice microsatellite markers associated with agronomic traits on a diverse collections, iii) study genetic variation for agronomic traits, (iv) provide useful information for a study on possible SSR functions and (v) demonstrate the utility of MTAs for agronomic traits.

\section{Materials and Methods}

Plant materials and phenotypic variation

A diverse collection of 22 Egyptian and exotic rice (Oryza sativa L.) genotypes were randomly selected and used to establish the experimental materials for this investigation. The genotypes were supplied by Agricultural Research Center [(ARC), Giza, Egypt], International Rice Research Institute, (Los Banos, Philippines) and National small grain collection, (USDA, ARS, USA). Details of rice genotypes presented in Table 1.

\section{Genomic DNA isolation}

DNA was extracted from fresh seedling leaves for each genotype following a modified CTAB method (McCouch et al., 1988). Based on the rice microsatellite genetic linkage map of Akagi et al. (1996) and Temnykh et al. (2000), 23 rice microsatellite (RM) markers were selected to represent the entire rice genome. The loci, chromosomal location, primer sequence, annealing temperature $\left({ }^{\circ} \mathrm{C}\right)$ and fragment size are presented in Table 2.

\section{Field experiment}

This investigation was carried out at the Experimental Farm of the Rice research and Training Center (RRTC), Sakha, Kafer El-Sheikh, Egypt. Divers collections utilized in this study were grown during the two rice succession growing seasons, 2011 and 2012. The experiment was arranged in a randomized complete block design (RCBD), with three replicates. Each rice genotype was transplanted into a plot; each plot comprised two rows, 5 meters long and contained 25 hills. Ordinary cultural practices for rice production were applied. 
TABLE 1. List of rice cultivars used in the study.

\begin{tabular}{|l|l|l|l|c|}
\hline No & Genotype Name & Origin & Source of seed & Subspecies Group \\
\hline 1 & IR 20 & Philippines & IRRI & Indica \\
\hline 2 & IR 22 & Philippines & IRRI & Indica \\
\hline 3 & IR 24 & Philippines & IRRI & Indica \\
\hline 4 & IR 50 & Philippines & IRRI & Indica \\
\hline 5 & IR 64 & Philippines & IRRI & Indica \\
\hline 6 & IR 74 & Philippines & IRRI & Indica \\
\hline 7 & Bala & India & IRRI & Indica \\
\hline 8 & IET 1444 & India & IRRI & Indica \\
\hline 9 & Arabi & Egypt & USDA, USA & Japonica \\
\hline 10 & Agamy M1 & Egypt & USDA, USA & Japonica \\
\hline 11 & Nahda & Egypt & USDA, USA & Japonica \\
\hline 12 & Yabani M1 & Egypt & USDA, USA & Japonica \\
\hline 13 & Yabani M7 & Egypt & USDA, USA & Japonica \\
\hline 14 & Yabani 15 & Egypt & USDA, USA & Japonica \\
\hline 15 & Yabani lulu & Egypt & USDA, USA & Japonica \\
\hline 16 & Giza 14 & Egypt & USDA, USA & Japonica \\
\hline 17 & Giza 171 & Egypt & ARC, Egypt & Japonica \\
\hline 18 & Giza 172 & Egypt & ARC, Egypt & Japonica \\
\hline 19 & Giza 177 & Egypt & ARC, Egypt & Japonica \\
\hline 20 & Giza 178 & Egypt & ARC, Egypt & Indica/ Japonica \\
\hline 21 & Giza 181 & Egypt & ARC, Egypt & Indica \\
\hline 22 & Gz 1386-5-4 & Egypt & ARC, Egypt & Indica \\
\hline
\end{tabular}

TABLE 2. SSR markers, chromosomal location, motive, annealing temperature $\left({ }^{\circ} \mathrm{C}\right)$, repeat category and expected fragment size.

\begin{tabular}{|c|c|c|c|c|c|c|}
\hline No. & $\begin{array}{c}\text { SSR } \\
\text { markers }\end{array}$ & $\begin{array}{c}\text { Chromosoma } \\
\text { l location }\end{array}$ & Motif & $\begin{array}{c}\text { Annealing } \\
\text { temperature } \\
\left({ }^{\circ} \mathrm{C}\right)\end{array}$ & $\begin{array}{c}\text { Repeat } \\
\text { category }\end{array}$ & $\begin{array}{c}\text { Expected } \\
\text { Fragment } \\
\text { size (bp) }\end{array}$ \\
\hline 1 & $R M 5$ & 1 & (GA)14 & 55 & di & 84 \\
\hline 2 & $R M 151$ & 1 & (TA)23 & 55 & di & 197 \\
\hline 3 & RM6 & 2 & (AG)16 & 55 & di & 163 \\
\hline 4 & $R M 154$ & 2 & (GA)21 & 60 & di & 106 \\
\hline 5 & $R M 22$ & 3 & (GA)22 & 55 & - & 194 \\
\hline 6 & RM55 & 3 & (GA)17 & 55 & di & 213 \\
\hline 7 & RM307 & 4 & (AT)14(GT)21 & 55 & complex & 104 \\
\hline 8 & RM161 & 5 & $(\mathrm{AG}) 20$ & 60 & $\mathrm{di}$ & 116 \\
\hline 9 & $R M 413$ & 5 & $(\mathrm{AG}) 11$ & 50 & di & 65 \\
\hline 10 & $R M 133$ & 6 & $(\mathrm{CT}) 8$ & 60 & di & 224 \\
\hline 11 & $R M 162$ & 6 & (AC)20 & 60 & di & 130 \\
\hline 12 & $R M 11$ & 7 & (GA)17 & 55 & di & 115 \\
\hline 13 & $R M 118$ & 7 & $(\mathrm{GA}) 8$ & 60 & di & 106 \\
\hline 14 & RM408 & 8 & (CT)13 & 55 & di & 109 \\
\hline 15 & $R M 433$ & 8 & (AG)13 & 50 & di & 215 \\
\hline 16 & $R M 215$ & 9 & (CT)16 & 55 & di & 126 \\
\hline 17 & $R M 285$ & 9 & (GA)12 & 55 & - & 205 \\
\hline 18 & $R M 271$ & 10 & (GA)15 & 55 & di & 65 \\
\hline 19 & $R M 474$ & 10 & (AT)13 & 55 & di & 195 \\
\hline 20 & RM552 & 11 & $(\mathrm{TAT}) 13$ & 55 & tri & 153 \\
\hline 21 & $R M 144$ & 11 & (ATT)11 & 55 & tri & 208 \\
\hline 22 & $R M 19$ & 12 & (ATC)10 & 55 & tri & 195 \\
\hline 23 & $R M 277$ & 12 & (GA)11 & 55 & di & 108 \\
\hline
\end{tabular}

Egypt. J. Bot., 56, No. 1 (2016) 


\section{Evaluation of agronomic traits}

In total, 7 traits were scored for each genotype. The symbolization of $Q T L s$ follows the rules of MacIntosh et al. (2003) (Table 3). Ten guarded of each genotype from each replicate were selected randomly to determine characteristic phenotypes, including heading date $(H d)$, plant height $(H t)$, panicle length $(P l)$, number of panicles per plant $(N o P)$, number of filled grains per panicle (Nofg), 1000-grain weight (Tgw) and grain yield per plant (Gyp).

\section{Microsatellite markers analysis}

A total of 23 rice microsatellite markers were selected for genotyping as given in Table 2. SSR markers were chosen on the basis of their proximity to genome specificity and according to information available in the Rice Genesdatabase (http:// www.gramene.org/microsat/Rmprimers. html) most of the marker positions within chromosomes were based on the published rice microsatellite from work map. Microsatellite amplifications, polymerase chain reaction and fragment analysis for SSR markers were performed according to Akagi et al. (1996) and Temnykh et al. (2000). Rice microsatellite (RM) designation, chromosomal location, motif, annealing temperature $\left({ }^{\circ} \mathbf{C}\right)$ and fragment size location in 'IR 36' (bp) of the amplified loci were reported by Akagi et al. (1996) and Temnykh et al. (2000).

\section{Statistical analysis}

Data on each of the 7 agronomic traits were separately correlated t each of the 23 polymorphic rice microsatellite markers. When a genotype showed its heterozygosity at a certain SSR locus, the molecular weight for that SSR marker in that accession was represented by the mean of two allele size. Correlation was determined by applying Pearson's method. Statistical significance was defined at $P<0.05$. The coefficient of determination $\left(\mathrm{R}^{2}\right)$ was estimated for each of SSR markers using SPSS 10.5 software (SPSS, Inc., Chicago, USA).

\section{Association analysis}

\section{Results}

Significant association was observed for 17 of the 23 polymorphic microsatellite markers with at least one of the 7 agronomic traits and the 23 markers identified with $\mathrm{R}^{2}>10 \%$ for traits (explained more than $10 \%$ of the phenotypic variation for each trait) (Table 3). In total, 24 marker-trait associations, significant QTLs for agronomic traits were identified. More QTLs were located on 2 and 7 chromosomes. The QTLs were distributed across 12 chromosomes, ranging from $1 Q T L$ on chromosomes $6,8,9,10$ and 12 to 4 QTls located on chromosomes 2 and 7 , respectively. In this study, the microsatellite markers RM6, RM118, RM151 and RM307 were appropriate MTAs to improve agronomic traits because most of agronomic related traits such as $\mathrm{Hd}, \mathrm{Ht}, \mathrm{Pl}, \mathrm{NoP}, \mathrm{Nofg}, \mathrm{Tgw}$ and $\mathrm{Gyp}$ were significant with these 
microsatellite markers. A higher $\mathrm{R}^{2}$ values were obtained for most agronomic traits and ranged from $-0.366^{*}$ to $0.695^{* *}$ for grain yield per plant and plant height, respectively. In total, 24 detected QTLs, 14 QTLs for $\mathrm{Hd}, \mathrm{Ht}, \mathrm{Pl}, \mathrm{Nop}$, Nofg, Tgw and Gyp might be the same as that obtained in earlier studies.

TABLE 3. Association of microsatellite markers with agronomic traits.

\begin{tabular}{|c|c|c|c|c|}
\hline Trait & $Q T L$ symbol & Chromosome & Marker & R-value \\
\hline \multirow{2}{*}{ Heading date $(H d)$} & QHd.RRTC.1.1 & 1 & $R M 151$ & $-0.471 *$ \\
\hline & QHd.RRTC.2.2 & 2 & RM006 & $-0.387^{*}$ \\
\hline \multirow{10}{*}{ Plant height $(H t)$} & QHt.RRTC.2.1 & 2 & RM006 & $-0.512 * *$ \\
\hline & QHt.RRTC.2.2 & 2 & $R M 154$ & $0.427 *$ \\
\hline & QHt.RRTC.3.3 & 3 & $R M 022$ & $-0.506^{* *}$ \\
\hline & QHt.RRTC.3.4 & 3 & $R M 055$ & $-0.362 *$ \\
\hline & QHt.RRTC.5.5 & 5 & $R M 161$ & $0.694 * *$ \\
\hline & QHt.RRTC.5.6 & 5 & $R M 413$ & $-0.440^{*}$ \\
\hline & QHt.RRTC.6.7 & 6 & $R M 162$ & $0.695 * *$ \\
\hline & QHt.RRTC.7.8 & 7 & RM011 & $-0.645^{* *}$ \\
\hline & QHt.RRTC.8.9 & 8 & $R M 433$ & $-0.632 * *$ \\
\hline & QHt.RRTC.12.10 & 12 & RM019 & $-0.610 * *$ \\
\hline \multirow{2}{*}{ Panicle length $(P l)$} & QPl.RRTC.4.1 & 4 & RM307 & $-0.426^{*}$ \\
\hline & QPl.RRTC.7.2 & 7 & $R M 118$ & $-0.600 * *$ \\
\hline \multirow[t]{4}{*}{$\begin{array}{l}\text { Number of panicles per plant } \\
(\text { Nop })\end{array}$} & QNop.RRTC.1.1 & 1 & RM005 & $-0.409 *$ \\
\hline & QNop.RRTC.2.2 & 2 & RM006 & $0.436 *$ \\
\hline & QNop.RRTC.7.3 & 7 & $R M 118$ & $-0.470 *$ \\
\hline & QNop.RRTC.11.4 & 11 & RM552 & -0.420 \\
\hline $\begin{array}{l}\text { Number of filled grains per } \\
\text { panicle (Nofg) }\end{array}$ & QNofg RRTC.1.1 & 1 & $R M 151$ & $0.506 * *$ \\
\hline 1000-grain weight $(T g w)$ & QTgw.RRTC.10.1 & 10 & $R M 271$ & $-0.412 *$ \\
\hline \multirow{4}{*}{ Grain yield per plant (Gyp) } & QGyp.RRTC.4.1 & 4 & RM307 & $-0.373^{*}$ \\
\hline & QGyp RRTC.7.2 & 7 & $R M 118$ & $-0.366^{*}$ \\
\hline & QGyp RRTC.9.3 & 9 & $R M 215$ & $-0.491 *$ \\
\hline & QGyp.RRTC.11.4 & 11 & RM552 & $-0.73 *$ \\
\hline
\end{tabular}

The statistics shown refer to the coefficient of determination $\left(\mathrm{R}^{2}\right)$, Only SSR markers with significant marker-trait association are given.

*,** Indicate significance at the probability levels of 0.05 and 0.01 , respectively.

$(H d)$ heading date, $(H t)$ plant height, $(P l)$, panicle length, $(N o P)$, number of panicles, (Nofg), number of filled grains (Tgw) 1000-grain weight and (Gyp) grain yield per plant.

Egypt. J. Bot., 56, No. 1 (2016) 
Marker-traits associations (MTAs) analysis

Heading date $(\mathrm{Hd})$

Correlation analysis indicated that there was a significant correlation in two QTLs $\left(\mathrm{r}=-0.387 *\right.$ to $\left.-0.471^{*}\right)$ of the 23 traits pairs between microsatellite allele size and $H d$ (Table 3). These two QTLs were designated as QHd.RRTC.1.1 and QHd.RRTC.2.2. Hd showed a significant correlation with the allele size of RM6 and RM151 on chromosomes 2 and 1 , respectively.

Plant height $(\mathrm{Ht})$

For $H t$, the correlation analysis indicated that there was a significant correlation in ten QTLs $\left(\mathrm{r}=-0.440^{*}\right.$ to $\left.0.695^{* *}\right)$ of 23 pair traits between microsatellite allele size and $H t$ (Table 3). These ten QTLs were designated as QHt.RRTC.2.1, QHt.RRTC.2.2, QHt.RRTC.3.3, QHt.RRTC.3.4, QHt.RRTC.5.5, QHt.RRTC.5.6, QHt.RRTC.6.7, QHt.RRTC.7.8, QHt.RRTC.8.9 and QHt.RRTC.12.10. $H t$ showed a significant correlation with the allele size of RM6, RM154, RM22, RM55, RM161, RM413, RM162, RM11, RM433 and RM19 on chromosomes 2, $3,5,6,7,8$ and 12 , respectively.

\section{Panicle length $(\mathrm{Pl})$}

From MTAs, there was a significant association with two QTLs $\left(\mathrm{r}=-0.426^{*}\right.$ to $-0.600^{* *}$ ) of 23 pair traits between microsatellite allele size and $P l$ (Table 3 ). These two QTLs were designated as QPl.RRTC.4.1 and QPl.RRTC.7.2. Pl had a significant association with allele size of RM307 and $R M 118$ on chromosomes 4 and 7 , respectively.

Number of panicles per plant (Nop): As for Nop, there was a significant correlation in four QTLs ( $\mathrm{r}=-0.409^{*}$ to $0.436^{*}$ ) of 23 pair traits between microsatellites allele size and Nop (Table 3). These four QTLs were designated as QNop.RRTC.1.1, QNop.RRTC.2.2, QNop.RRTC.7.3, and QNop.RRTC.11.4. Nop showed a significant correlation with some allele size of RM5, RM6, RM552 and RM118 on chromosomes 1,2,11 and 7, respectively.

Number of filled grains per panicle (Nofg): A significant MTAs only in one QTL $\left(\mathrm{r}=0.506^{* *}\right)$ of 23 pair traits was obtained between microsatellites allele size and Nofg (Table 3). These QTL was designated as QNofg.RRTC.1.1. Nofg showed a significant correlation with the allele size of $R M 151$ on chromosome 1.

1000-grain weight $(\mathrm{Tgw})$ : Concerning the $\mathrm{Tgw}$, there was a significant correlation in one $Q T L\left(\mathrm{r}=-0.412^{*}\right)$ of 23 pair traits between microsatellites allele size and Tgw (Table 3). These $Q T L$ was designated as QTgw.RRTC.10.1. Tgw showed a significant correlation with allele size of RM291 on chromosome 10. 
Grain yield per plant (Gyp): There was a significant correlation in four QTLs $\left(\mathrm{r}=-0.366^{*}\right.$ to $\left.0.491 *\right)$ of 23 pair traits between microsatellites allele size and Gyp (Table 3). These four QTLs were designated as QGyp.RRTC.4.1, QGyp.RRTC.7.2, QGyp.RRTC.9.3, and QGyp.RRTC.11.4. Gyp showed a significant correlation with allele size of $R M 215, R M 307, R M 552$ and $R M 118$ on chromosomes 9, 4, 11 and 7, respectively.

\section{Discussion}

Yield is the most important and complex trait for genetic improvement in cereal crops, and marker-assisted selection enhances the improvement of efficiency. Marker-trait associations (MTAs) offers a very good tool for rice breeders to obtained high yield. Selection can be done on the markers associated with the targeted traits by using DNA-markers. Once, the phenotypic traits are fixed, breeders can evaluate large numbers of progenies for yield performance in a conventional way. A combination of MTAs and conventional evaluation could significantly improve the breeding program efficiency, its process and new released cultivars (Collard and Mckill, 2008).

The association between markers and genes/QTLs controlling the targeted traits must be first established prior the marker associated selection (MAS) process. This study was conducted to identify QTLs correlated with agronomic traits in rice. Microsatellite markers used were well distributed amongst the 12 chromosomes, (Cho et al., 2000 and Temnykh et al., 2000). Heading date $(H d)$ is a major determinant of the regional and seasonal adaptation of rice varieties. Data presented in this study clearly identified two QTLs for $H d$ associated with two microsatellite markers $R M 6$ and $R M 151$ on chromosomes 1 and 2, respectively. Yamamoto et al. (2000), have a putative $Q T L$ for heading date $(H d)$ on chromosomes 2 and 3. For heading date, the $Q T L$ associated with $H d$ (QHd.RRTC.2.2) on chromosome 2, might be the same as that found recently (Yamamoto et al., 2000). Plant height (Ht) is one of the most important traits related to plant status and yield potential. In the current study, a total of ten $Q T L s$ were identified for plant height on chromosomes $2,3,5,6,7,8$ and 12 . There were several reported molecular marker based genetic analyses of plant height in rice, which detected a number of QTLs on chromosomes 1, 2, 4, 5, 6, 9 and 11 (Lin et al., 2011), Huang et al. (1996) analyzed QTLs for plant height in five rice populations and identified 13 major dwarfing genes were located in close proximity to these QTLs. Moreover, Yu et al. (2002) detected four QTLs for Ht on chromosomes 1, 5, 7, and 11. More recently, a gene for $\mathrm{Ht}$ on chromosome 5 was cloned using a map based cloning strategy (Ashikari et al., 1999) and on chromosomes 1, 3 and 7 (Hittalmani et al., 2003). With regard to Ht, 7 QTLs (QHt.RRTC.1.1, QHt.RRTC.2.2, QHt.RRTC.3.3, QHt.RRTC.3.4, QHt.RRTC.5.5, QHt.RRTC.5.6 and QHt.RRTC.7.8) from 10 detected were located on chromosomes 2, 3, 5, 6, 7, 8 and 12, respectively. The QTLs on chromosomes 2, $3,5,6$ and 7 respectively, might be the same as that found by Ashikari et al. (1999), Yu et al. (2002), Hittalmani et al. (2003) and Lin et al. (2011).

Egypt. J. Bot., 56, No. 1 (2016) 
For $P l$, two $Q T L s$ were associated with two rice microsatellite markers RM307 and RM118 on chromosomes 4 and 7. Ahamadi et al. (2008) found $Q T L s$ for $P l$ on chromosomes $2,4,11$, and 12 . In previous studies, the $Q T L$ (QPl.RRTC.4.1) for $\mathrm{Pl}$ on chromosome 4 might be the same as that found by Ahamadi et al. (2008). Concerning the Nop, four QTLs were associated with microsatellite markers RM5 RM5 RM6 RM118 and RM552 on chromosomes 1, 2, 7 and 11. Hittalmani et al. (2003) reported one QTL was detected for Nop on chromosomes 1, 4 and 12. Also, Zhu et al. (2011) detected QTL for Nop on chromosome 1. In this case, the QTL (QNop.RRTC.1.1) for Nop on chromosome 1 might be the same as that found recently by Hittalmani et al. (2003) and Zhu et al. ( 2011). Large number of well-filled grains per panicle (Nofg) is an important yield component trait in rice. In this study, QTL for Nofg was identified by SSR marker RM151 on chromosome 1. Ahamadi et al. (2008) detected a total of three $Q T L s$ for panicle grain number was on chromosomes 1 and 12. In this case, the QTL (QNofg.RRTC.1.1) for the number of filled grains on chromosome 1 might be the same as that found earlier by Ahamadi et al. (2008). 1000-grain weight ( $T g w)$ is an important factor affecting grain yield as well as grain quality in rice. In the present study, $Q T L$ for 1000-grain weight was associated with SSR marker RM271 on chromosome 10. Tang et al. (2013) found a number of QTLs for 1000-grain weight on chromosomes 2, 3, 5, 6, 8 and 10. In this case, the QTL (QTgw.RRTC.10.1) for 1000-grain weight on chromosome 10 might be the same as that found recently by Tang et al. (2013). $(G y p)$ is a complex trait consisting of several yield components. It is of great importance to reveal the genetic relationships between Gyp and its yield components at the $Q T L$ level for multi-trait improvement in rice. In the present study, four QTLs for Gyp were associated with microsatellite markers RM307, RM118, RM215 and RM552 on chromosomes 4, 7, 9 and 11. Liu et al. (2008) detected 10 QTLs for Gyp on chromosomes 1, 2, 3, 4, 7, 8, and 12. The QTLs (QGyp.RRTC.4.1 and QGyp.RRTC.7.2) for Gyp on chromosomes 4 and 7 might be as that found by Liu et al. (2008).

Marker trait association (MTA) is new approach in cereal genetics and particularly in rice. In contrast to conventional bi-parental mapping, which can only analyze allelic differences between two parents, association mapping attempts to scan genetic variation across a wide spectrum of genotypes. The present study underlines the value of genetic basis of agronomic traits even with a relatively small collection of genotypes. A substantial number of MTAs for the whole set of agronomic traits were detected. Many loci were detected that coincide with known major genes/QTLs for agronomic traits, indicating the power of association mapping. Additionally, potential novel loci were identified that may help to better understand the architecture of complex genetic traits. Based on marker approach, the novel loci provide opportunities for further improvement of rice. Breeders can use this information to design crosses that 
assemble new, potentially durable combinations of agronomic traits genes/QTLs to improve rice genotypes.

\section{References}

Agrama, H.A., Eizenga, G.C. and Yan, W. (2007) Association mapping of yield and its components in rice cultivars. Mol Breed, 19: 341-356.

Ahamadi, J., Fotokian, M.H. and Fabriki-Orang, S. (2008) Detection of QTLs influencing panicle length, panicle grain number and panicle grain sterility in rice (Oryza sativa L.). J. Crop Sci., Biotech, 11 (3) : 163-170.

Akagi, H., Y. Yohozeki, A. Inagaki, A. Nakamura and Fujimura, T. (1996) A codominant DNA marker closely linked to the rice nuclear restorer gene $R f-1$, identified with inter-SSR fingerprinting. Genome, 39: 1205-1209.

Ashikari, M., Wu, J., Yano, M., Sasaki, T. and Yoshimura, A. (1999) Rice gibberellin-insensitive dwarf mutant gene dwarf 1 encodes the a-subunit of GTPbinding protein. Proc. Natl. Acad. Sci., USA 96:10284-10289.

Bernardo, R. (2008) Molecular markers and selection for complex traits in plants: learning from the last 20 years. Crop Sci., 48:1649-1664.

Cho. YG., Ishii, T.,Temnykh, S., Chen, X., Lipovich, L., McCouch, S.R., Park, W.D., Ayres, N. and Cartinhour, S. (2000) Diversity of microsatellites derived from genomic libraries and gen bank sequences in rice (Oryza sativa L.). Theor. and Appl. Genet, 100(5): 713-722.

Collard, B.C. and Mackill, D.J. (2008) Marker assisted selection: An approach for precision plant breeding in the twenty-first century. Philos. Trans. Roy. Soc. Lond B Biol. Sci., 363: 557-572.

Cooper, M., Podlich, D.W. and Smith, O.S. (2005) Gene-to-phenotype models and complex trait genetics. Aust. J. Agric. Res., 56: 895-918 .

Delseny, M., Salses, J., Cooke, R., Sallaud, C., Regad, F., Lagoda, P., Guiderdoni, E., Ventelon, M., Brugidou, C. and Ghesquière, A. (2001) Rice genomics: Present and future. Plant Physiol Biochem, 39(3/4): 323-334.

Dixit, N., Dokku, P., Amitha Mithra S.V., Parida, S.K., Singh, A.K., Singh, N.K. and Mohapatra, T. (2013) Haplotype structure in grain weight gene $G W 2$ and its association with grain characteristics in rice. Euphytica, 192 (1): 55-61.

Fan, C., Yu, S., Wang, C. and Xing, Y. (2009) A causal C-A mutation in the second exon of GS3 highly associated with rice grain length and validated as a functional marker. Theor. Appl. Genet. 118: 465-472.

Feng, Y., Zhai, R. R., Lin, Z. C., Cao, L. Y., Wei, X. H. and Cheng, S. H. (2013) $Q T L$ analysis for yield traits in rice under two nitrogen levels. Chin. J. Rice. Sci., 27 (6): 577-584. (in Chinese with English abstract).

Egypt. J. Bot., 56, No. 1 (2016) 
Flint-Garcia S.A., Thornsberry, J.M. and Buckler, E.S. (2003) Structure of linkage disequilibrium in plants. Annu. Rev. Plant. Biol., 54: 357-374 .

Flint-Garcia, S.A., Thuillet, A.C., Yu, J., Pressoir, G., Romero, S.M., Mitchell, S.E., Doebley, J., Kresovich, S., Goodman, M.M. and Buckler, E.S. (2005) Maize association population: a high-resolution platform for quantitative trait locus dissection. Plant J., 44:1054-1064 .

Fukuoka, S., Saka, N., Koga, H., Ono, K., Shimizu, T., Ebana, K., Hayashi, N., Takahashi, A., Hirochika, H., Okuno, K. and Yano, M. (2009) Loss of function of a proline-containing protein confers durable disease resistance in rice. Science., 325: 998-1001.

Hittalmani, S., Huang, N., Courtois, B., Venuprasad, R., Shashidhar, H.E., Zhuang, J.Y, Zheng, K.L., Liu, G.F, Wang, G.C., Sidhu, J.S., Srivantaneeyakul, S., Singh, V.P, Bagali, P.G., Prasanna, H.C., McLaren, G. and Khush, G.S. (2003) Identification of $Q T L$ for growth and grain yield-related traits in rice across nine locations of Asia. Theor. Appl. Genet., 107: 679-690.

Holland, J. (2007) Genetic architecture of complex traits in plants. Curr. Opin. Plant. Biol., 10:156-161

Huang, N., Courtois, B., Khush, G.S., Lin, H.X., Wang, G.L., Wu, P. and Zheng, K.L. (1996) Association of quantitative trait loci for plant height with major dwarfing genes in rice. Heredity, 77:130-137.

Inostroza, L., Pozo, A.D., Matus, I., Castillo, D., Hayes, P., Machado, S. and Corey, A. (2009) Association mapping of plant height, yield, and yield stability in recombinant chromosome substitution lines (RCSLs) using Hordeum vulgaresubsp. spontaneum as a source of donor alleles in a Hordeum vulgare Subsp. vulgare background. Mol. Breed, 23: 365-376.

Iwata, H., Uga, Y., Yoshioka, Y., Ebana, K. and Hayashi, T. (2007) Bayesian association mapping of multiple quantitative trait loci and its application to the analysis of genetic variation among Oryza sativa L. germplasms. Theor. Appl. Genet., 114:1437-1449 .

Jiang, G.H., Xu, C.G., Li, X.H. and He, Y.Q. (2004) Characterization of the genetic basis for yield and its component traits of rice revealed by doubled haploid population. Acta Genet Sinicavol, 31: 63-72 .

Kraakman, A.T., Niks, R.E., Van den Berg P.M., Stam, P., Van and Eeuwijk, F.A. (2004) Linkage disequilibrium mapping of yield and yield stability in modern spring barley cultivars. Genetics, 168: 435-446.

Li Y, Fan C, Xing Y, Jiang Y, Luo L, Sun L, Shao D, Xu C, Li X, Xiao J, He Y, Zhang Q (2011) Natural variation in GS5 plays an important role in regulating grain size and yield in rice. Nat, Genet., Doi:10.1038/ng.977.

Egypt. J. Bot., 56, No. 1 (2016) 
Lin, Y.R., Wu, S.C., Chen, S.E., Tseng, T.H., Chen, C.S., Kuo, S.C., Wu, H.P. and Hsing, Y.I. (2011) Mapping of quantitative trait loci for plant height and heading date in two inter-sub specific crosses of rice and comparison across Oryza genus. Botanic. Stud., 52: 1-14.

Liu, G.F., Yang, J., Xu, H.M., Hayat, Y. and Zhu, J. (2008) Genetic analysis of grain yield conditioned on its component traits in rice (Oryza sativa L.). Aust. J. of Agricult. Resea., 59: 189-195

Mazzucato, A., Papa, R., Bitocchi, E., Mosconi, P., Nanni, L., Negri, V., Picarella, M.E, Siligato, F., Soressi, G.P., Tiranti, B. and Veronesi, F. (2008) Genetic diversity, structure and marker-trait associations in a collection of Italian tomato (Solanum lycopersicum L.) landraces. Theor. Appl. Genet., 116: 657-669

McCouch, S.R., G Kochert, Z. H. Yu, Z.Y. Wang, G.S. Khush, W.A. Coffman and S.D. Tanksley (1988) Molecular mapping of rice chromosome. Theor. Appl. Genet., 76: $815-829$.

McIntosh, R. A., Y. Yamazaki, K. M. Devos, J. Dubkovsky, W. J. Rogers. and R. Appels. (2003). MacGene 2003-Catalogue of gene symbols for wheat. CD, In: "Proc 10th Int Wheat Genet Symp", Paestum, Italy .

Moncada, P., Martinez, C.P., Borrero, J., Chatel, M., Gauch, H., Guimaraes, E., Tohme, J. and McCouch, S.R. (2001) Quantitative trait loci for yield and yield components in an Oryza sativa $\times$ Oryza rufipogon $\mathrm{BC}_{2} \mathrm{~F}_{2}$ population evaluated in an upland environment. Theor. Appl. Genet., 102:41-52.

Shi, J., Li, R., Qiu, D., Jiang, C., Long, Y., Morgan, C., Bancroft, I., Zhao, J. and Meng, J. (2009) Unraveling the complex trait of crop yield with quantitative trait loci mapping in Brassica napus. Genetics, 182:851-861

Stich, B., Möhring, J., Piepho, H.P., Heckenberger, M., Buckler, E.S. and Melchinger, A.E. (2008) Comparison of mixed-model approaches for association mapping. Genetics, 178: 1745-1754 .

Suh, J.P., Ahn, S.N., Cho, Y.C., Kang, K.H., Choi, I.S., Kim, Y.G., Suh, H.S. and Hong, H.C. (2005) Mapping of QTLs for yield traits using an advanced backcross population from a cross between Oryza sativa and O. glaberrima. Korean J. Breed, 37: $214-220$.

Takeuchi, Y., Ebitani, T., Yamamoto, T., Sato, H., Ohta, H., Hirabayashi, H., Kato, H., Ando, I., Nemoto, H., Imbe, T. and Yano, M., (2006) Development of isogenic lines of rice cultivar Koshihikari with early and late heading by marker-assisted selection. Breed Sci., 56: 405-13.

Tang, S., Shao, G., Wei, X., Chen, M., Sheng, Z., Luo, J., Jiao, G., Xie, L. and Hu, P. (2013) QTL mapping of grain weight in rice and the validation of the QTL qTGW3.2. Gene., 527(1): 201-206 
Temnykh, S., Park, W.D. Ayres, N., Cartinhour, S., Hauck, N., Lipovich, I., Cho, Y.G., Ishii, T. and McCouch, S.R., (2000) Mapping and genome organization of microsatellite sequences in rice (Oryza sativa L.). Theor. Appl. Genet., 100: 697-712.

Thornsberry, J.M., Goodman, M.M., Doebley, J., Kresovich, S., Nielsen, D. and Buckler, E.S. (2001) Dwarf8 polymorphisms associate with variation in flowering time. Nat Genet, 28: 286-289

Xu, F., Tang, F., Shao, Y., Chen, Y., Tong, C. and Bao, J. (2014) Genotype environment interactions for agronomic traits of rice revealed by association mapping. Rice Sci., 21(3): 133-141

Yamamoto, T., Yonemaru, J. and Yano, M. (2009) Towards the understanding of complex traits in rice: substantially or superficially? DNA Res., 16:141-54.

Yamamoto, T., Lin, H., Sasaki, T. and Yano, M. (2000) Identification of heading date quantitative trait locus Hd6 and characterization of its epistatic interactions with Hd2 in rice using advanced backcross progeny. Genetics, 154: 885-89.

Yu, S.B., JX, Li, JX, Xu CG, Tan YF and Li XH (2002) Identification of quantitative trait loci and epistatic interactions for plant height and heading date in rice. Theor. Appl. Genet., 104: 619-625.

Zeng, Y., Zhang, H., Yang, S., Du, J., Pu, X., Wang, L., Liu, J., Xiao, F. and Li, Z. (2009) Correlation between allele sizes of microsatellites and phenotypic variations in rice landraces. Front. Agric. China., 3: 130-139.

Zhang, N., Xu, Y., Akash, M., McCouch, S. and Oard, J.H. (2005) Identification of candidate markers associated with agronomic traits in rice using discriminant analysis. Theor. Appl. Genet., 110: 721-729.

Zhu, C.S., Gore, M., Buckler, E.S. and Yu, J.M. (2008) Status and prospects of association mapping in plants. Plant Genome, 1: 5-20

Zhu, J., Zhou, Y., Liu, Y.,Wang, Z., Tang, Z., Yi, C., Tang, S., Gu, M. and Liang, G. (2011) Fine mapping of a major $Q T L$ controlling panicle number in rice. Mol. Breeding, 27: 171-180. 


\section{تحديد المعلمات الجزيئية المرتبطة بالصفات المحصولية فى الأرز}

(Oryza sativa L.)

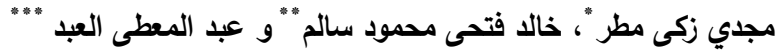

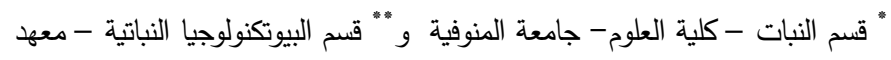

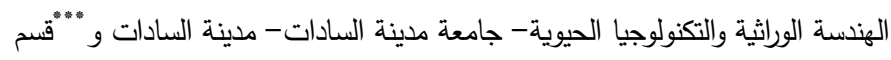

$$
\begin{aligned}
& \text { بحوث الأرز - معهد بحوث المحاصيل - مركز البحوث الزراعية - الجيزة - مصر. }
\end{aligned}
$$

يُعد استخدام المعلم الجزيئى الميكروستاليت (microsatellite) هام لتحديد التحريد

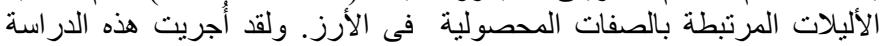

$$
\text { تحديد الكرموسومات التي تتحكم في ور اثة الصفات المحصولية. }
$$

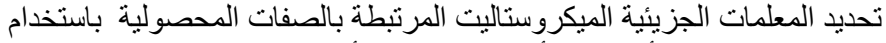

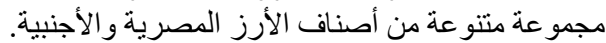

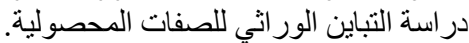

توفير المعلومات الهامة للأستفادة من الأهمية الوظيفية للمعلم الجزيئي الميكروستاليت.

اثبات فائدة استخدام الأنتخاب باستخدام المعلمات الجزيئية للصفات المحصولية.

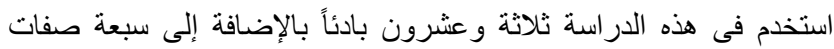

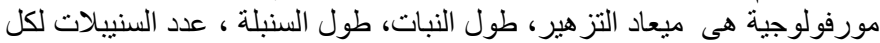

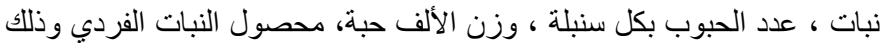

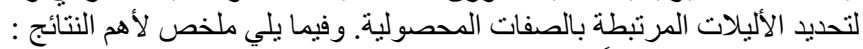

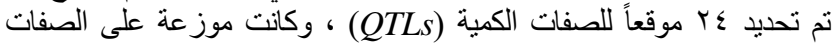

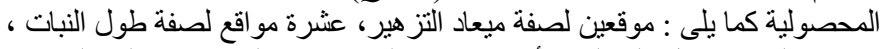

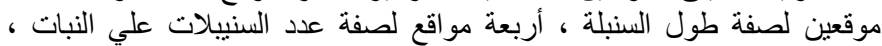

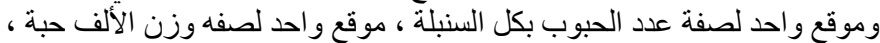
و واربعة مو اقع لصفه محصول النبات الفردي. ووجد أن معظم هذه المو اقع موجود الهود

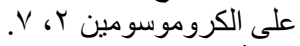

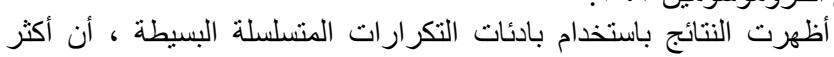

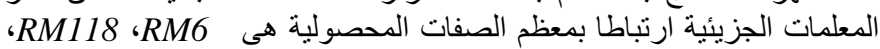

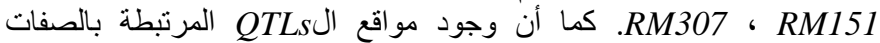
المحصولية على كروموسومات مختلفة مما يدل على ألى أنه قد يتحكم في ور اثنه عديد الثيد

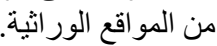

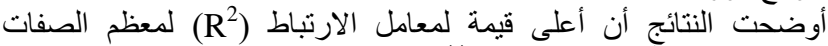

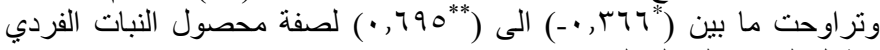

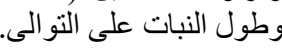

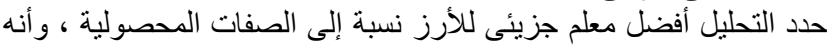

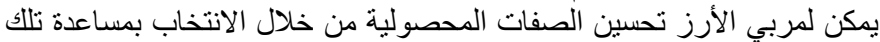

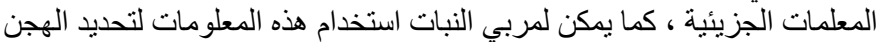
التي تجمع تر اكيب جينية QTLs جديدة ، لتحسين التر اكيب الور اثية في الأرز. 